\title{
Effect of indolebutyric acid and cutting type on vegetative propagation of three Lippia species
}

\author{
Acido indolbutírico e tipo de estaca na propagação \\ vegetativa de três espécies de Lippia
}

Luma dos Passos Bispo ${ }^{\mathrm{I}}$ Lenaldo Muniz de Oliveira ${ }^{\text {II }}$ Marilza Neves do Nascimento ${ }^{\text {II }}$ Carlos Alberto da Silva Ledo ${ }^{\text {III }}$

\section{- NOTE -}

\begin{abstract}
The objective of this study was to evaluate the effect of different types of cuttings and indolebutyric acid (IBA) concentration on the vegetative propagation of Lippia insignis, L. lasiocalycina, and L. thymoides. The experiment was conducted in a $2 \times 5$ factorial table, by using 2 types of cuttings (apical and medial) and 5 IBA concentrations $\left(0,250,500,750\right.$, and $\left.1000 \mathrm{mg} \cdot \mathrm{L}^{-1}\right)$ in a Completely Randomized Design (CRD), with 4 replications and 10 cuttings per plot. For the propagation of $\boldsymbol{L}$. insignis, apical cuttings are the most suitable, whereas for L. thymoides and L. lasiocalycina species, both apical and medial cuttings may be used. The application of IBA is not necessary for propagation by cutting of the three species of Lippia.
\end{abstract}

Key words: Lippia insignis, L. lasiocalycina, L. thymoides, Verbenaceae, rooting.

\section{RESUMO}

Este estudo teve como objetivo avaliar o efeito de diferentes tipos de estacas e ácido indolbutírico (AIB) na propagação vegetativa de Lippia insignis, L. lasiocalycina e L. thymoides. O experimento foi conduzido em esquema fatorial $2 \times 5$, sendo dois tipos de estacas (apicais e medianas) e cinco concentrações de AIB (0, 250, 500, 750 e $1000 \mathrm{mg} \mathrm{L}^{-1}$ ), em Delineamento Inteiramente Casualizado (DIC), com quatro repetições e dez estacas por parcela. $\mathrm{Na}$ propagação de L. insignis, estacas apicais são as mais indicadas, enquanto que, tanto as estacas apicais como medianas, podem ser utilizadas para a propagação das espécie $\mathbf{L}$. thymoides e $\boldsymbol{L}$. lasiocalycina. Não é necessária a aplicação de AIB na propagação por estaquia das três espécies de Lippia.

Palavras-chave: Lippia insignis, L. lasiocalycina, L. thymoides, Verbenaceae, enraizamento.
Lippia is one of the largest genera of the Verbenaceae family, composed of herbs, shrubs, and small trees, which are often aromatic, and are distributed throughout south and central america, and central africa (BLANK, 2013). Lippia includes a variety of species with medicinal and aromatic properties, and approximately $75 \%$ of the known species are found in Brazil, which makes the country a center of diversity for the genus (VICCINI et al., 2006). Despite their well-known economic potential, there is a dearth of information on Lippia species, preventing their sustainable use (PIMENTA et al., 2007; LORENZI \& MATOS, 2008). To our knowledge there are no studies on the propagation and cultivation of the species $\boldsymbol{L}$. insignis, L. lasiocalycina, and $L$. thymoides.

Seed propagation is one of the main problems limiting the proliferation of these species because the seeds, in addition to being very small, develop mechanisms that hinder germination (LORENZI \& MATOS, 2008; PIMENTA et al., 2007). Conversely, propagation by cuttings has been a viable alternative used efficiently in the proliferation of some species of this genus (TAVARES et al., 2012; PIMENTA et al., 2007). The present study aimed to evaluate the effect of types of cuttings and indolebutyric acid concentration on the vegetative propagation of $\boldsymbol{L}$. insignis Moldenke, L. lasiocalycina Cham., and L. thymoides Martius \& Schauer.

\footnotetext{
IPrograma de Pós-graduação em Recursos Genéticos Vegetais, Universidade Estadual de Feira de Santana (UEFS), 44036.900, Feira de Santana, BA, Brasil. E-mail: luma.pb@hotmail.com. Corresponding author.

IDepartamento de Ciências Biológicas, Universidade Estadual de Feira de Santana (UEFS), Feira de Santana, BA, Brasil.

IIIEmbrapa Mandioca e Fruticultura (CNPMF), Cruz das Almas, BA, Brasil. 
The experiment was carried out during July to October 2013. Cuttings were taken from 2-year-old mother plants of the three species and maintained in the Aromatic Plants Collection of the Forest Botanic Garden of Universidade Estadual de Feira de Santana, Bahia, Brazil. The experiment was carried out using a $2 \times 5$ factorial table, and two types of cuttings (apical and medial) and five concentrations of IBA $(0,250$, 500,750 , and $\left.1000 \mathrm{mg} \cdot \mathrm{L}^{-1}\right)$ were used. The treatments were arranged in a Completely Randomized Design (CRD) with four replications of ten cuttings per plot, separated essays and simultaneous trials by species. It was used cuttings of $10 \mathrm{~cm}$, with a few leaves cut in the middle. One-third of the length of each cutting (at the base) was immersed in IBA solutions for $2 \mathrm{~h}$, while the control cuttings were immersed in distilled water for the same period. The treated cuttings were planted in polystyrene trays filled with Biomix ${ }^{\circledR}$ commercial substrate. After planting, the cuttings were maintained in a greenhouse with a transparent plastic cover, under $75 \%$ luminosity, $60 \%$ humidity, and temperatures averaging $27^{\circ} \mathrm{C}$, with intermittent spraying for $4 \mathrm{~min}$ every hour.

After 60 days of cultivation, the following assessments were made: survival percentages by observing at least one visible sprout; rooting by observing at least one visible root; number of shoots per cutting; number of leaves per shoot; shoot length; and dry mass of shoots and roots. The data obtained were subjected to analysis of variance and analysis of comparative averages by using the Tukey test at 5\% probability of error.
For IBA concentrations, a regression analysis was carried out. In all analyses, the percentage data were transformed into $\operatorname{ArcSin}(\sqrt{ } \mathrm{x} / 100)$.

The variance analysis did not confirm an interaction between the type of cutting and IBA concentration. However, it detected a significant difference in the effect of isolated factors assessed for all species. L. lasiocalycina had the highest number of shoots per cutting, leaves per shoot, shoot length, and dry mass of roots and shoots when using medial cuttings (Table 1). For L. thymoides, the apical cuttings showed superior results for length and dry mass of shoots (Table 1). For $\boldsymbol{L}$. insignis, the highest averages for survival percentage and rooting of cuttings were obtained with apical cuttings (Table 1).

BIASI \& COSTA (2003) and TAVARES et al. (2012) also reported that rooting in $\boldsymbol{L}$. alba was not influenced by the types of cuttings tested. Studies have shown that $\boldsymbol{L}$. sidoides cuttings had difficult rooting and that apical cuttings yielded the best results (OLIVEIRA et al., 2008). However, the rooting ability of the Lippia species investigated in this study was relatively high, ranging from $79.0 \%$ to $95.5 \%$ (apical cuttings) and $69.5 \%$ to $91.5 \%$ (medial cuttings), demonstrating easy root formation. On the contrary, PIMENTA et al. (2007) reported that non-domesticated species of Lippia showed an average of 0-11.1 roots per cutting. Thus, the best area of the branch of a plant to obtain a cutting varies with the species, as well as the physiological condition of the plant.

At different IBA concentrations, $\boldsymbol{L}$. insignis yielded significant results for dry mass of

Table 1 - Survival percentage (SUR), rooting percentage (ROO), average number of shoots per cutting (NS), number of leaves per shoot (NL), length of shoots (LS), dry mass of shoots (DMS), and dry mass of roots (DMR) of Lippia insignis Moldenke, Lippia lasiocalycina Cham, and Lippia thymoides Martius \& Schauer, obtained from apical and medial cuttings at Feira de Santana, Bahia, UEFS, 2013.

\begin{tabular}{|c|c|c|c|c|c|c|c|}
\hline \multirow{2}{*}{ Treatment } & \multirow[b]{2}{*}{ SUR (\%) } & \multirow[b]{2}{*}{ ROO (\%) } & \multirow[b]{2}{*}{ NS } & \multirow[b]{2}{*}{$\mathrm{NL}$} & \multirow[b]{2}{*}{$\mathrm{LS}(\mathrm{cm})$} & \multirow[b]{2}{*}{ DMS (g) } & \multirow[b]{2}{*}{ DMR $(\mathrm{g}$} \\
\hline & & & & & & & \\
\hline Type of cutting & & & & --Speci & --------- & 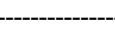 & (-3) \\
\hline Apical & $89.00 \mathrm{a}$ & $89.00 \mathrm{a}$ & $1.50 \mathrm{a}$ & $6.04 \mathrm{a}$ & $2.44 \mathrm{a}$ & $0.09 \mathrm{a}$ & $0.10 \mathrm{a}$ \\
\hline Medial & $70.50 \mathrm{~b}$ & $69.50 \mathrm{~b}$ & $1.20 \mathrm{~b}$ & $5.76 \mathrm{a}$ & $2.59 \mathrm{a}$ & $0.08 \mathrm{a}$ & $0.09 \mathrm{a}$ \\
\hline Apical & $83.00 \mathrm{a}$ & $79.00 \mathrm{a}$ & $0.81 \mathrm{~b}$ & $\begin{array}{r}\text { Iasiocal } \\
3.65 \mathrm{~b}\end{array}$ & $0.80 \mathrm{~b}$ & $0.04 \mathrm{~b}$ & $0.09 \mathrm{~b}$ \\
\hline Medial & $78.50 \mathrm{a}$ & $75.50 \mathrm{a}$ & $1.04 \mathrm{a}$ & $4.76 \mathrm{a}$ & $1.35 \mathrm{a}$ & $0.07 \mathrm{a}$ & $0.12 \mathrm{a}$ \\
\hline Apical & $95.50 \mathrm{a}$ & $95.50 \mathrm{a}$ & $2.50 \mathrm{a}$ & - & $3.71 \mathrm{a}$ & $0.08 \mathrm{a}$ & $0.06 \mathrm{a}$ \\
\hline Medial & $91.50 \mathrm{a}$ & $91.50 \mathrm{a}$ & $2.15 \mathrm{a}$ & - & $2.57 \mathrm{~b}$ & $0.05 \mathrm{~b}$ & $0.05 \mathrm{a}$ \\
\hline
\end{tabular}

Averages followed by different letters in the same column and for each species differ according to the Tukey test at $5 \%$ probability of error. 
roots and shoots. However, the results did not fit to a model of statistical significance, since $250 \mathrm{mg} \cdot \mathrm{L}^{-}$ ${ }^{1}$ IBA promoted the best results for both variables (Figures 1A and 1B). For L. lasiocalycina, treatments with increasing IBA concentration resulted in a linear decrease in the survival percentage, with the highest percentage $(92.5 \%)$ obtained when IBA was not used (Figure 1C). A similar effect was reported for the number of shoots per cutting and number of leaves per shoot, with the highest averages obtained when a plant growth regulator was not used (Figures $1 \mathrm{D}$ and $1 \mathrm{E})$. Although a representative mathematical model has not been obtained, the results show that the concentrations of IBA promoted differences in the length of sprouts and dry mass of shoots and roots, with the $250 \mathrm{mg} \cdot \mathrm{L}^{-1}$ IBA treatment being the most efficient (Figures 1F, 1G, and 1H). For L. thymoides, an ascending linear effect of IBA concentrations was observed on the number of shoots per cutting (Figure 1I). Further, increasing IBA concentrations promoted quadratic responses in the length of the sprouts, with an estimated length of $4.01 \mathrm{~cm}$ resulting from the use of $762.5 \mathrm{mg} \cdot \mathrm{L}^{-1}$ IBA (Figure 1J). For dry mass of roots and shoots, an ascending linear behavior was observed with increasing IBA concentrations (Figures $1 \mathrm{~K}$ and $1 \mathrm{~L}$ ). PAULUS et al. (2014) obtained similar results when evaluating the effect of $1500 \mathrm{mg} \cdot \mathrm{L}^{-}$

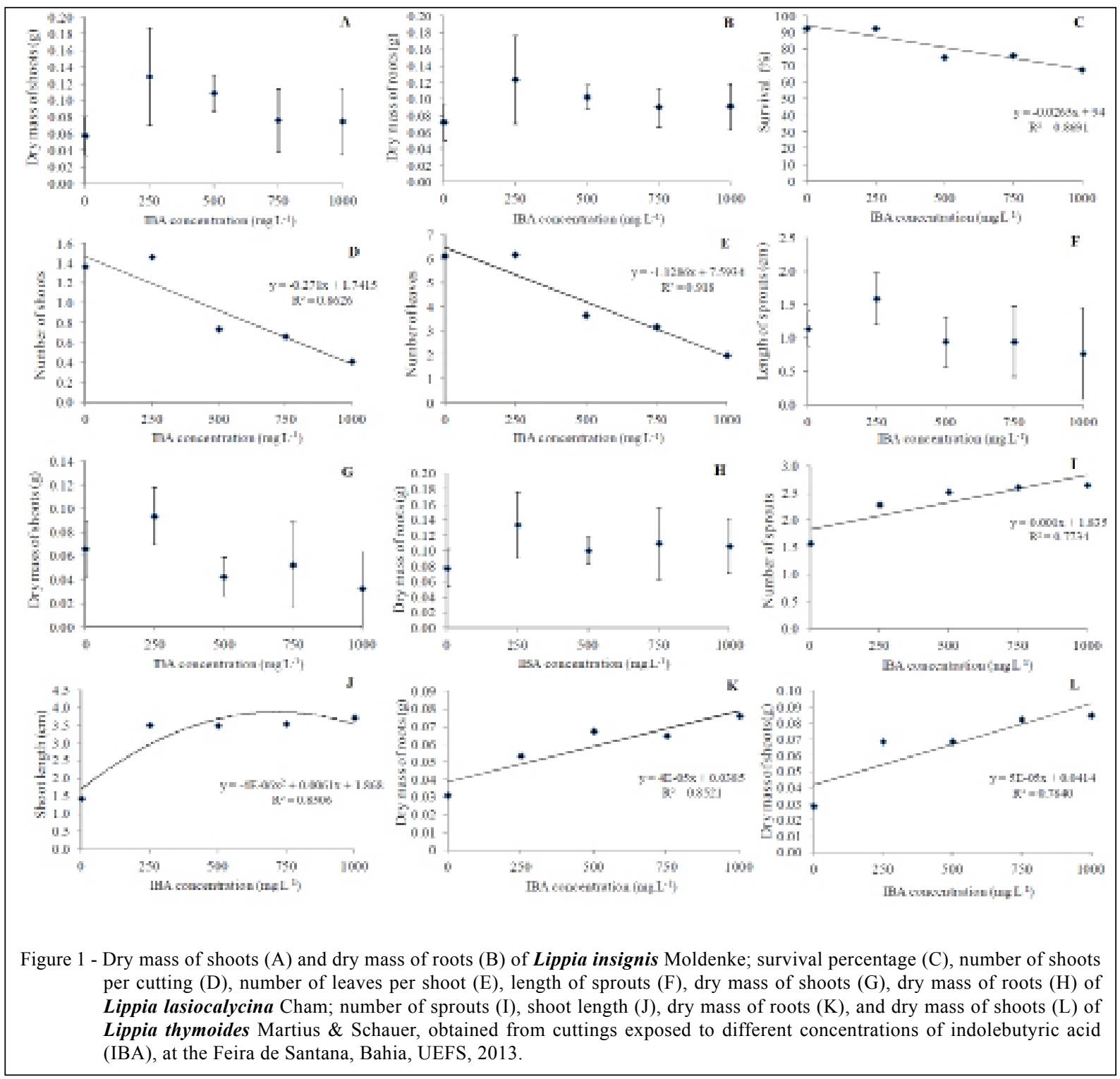

Ciência Rural, v.46, n.8, ago, 2016. 
1 IBA on the vegetative propagation of Aloysia triphylla, which resulted in an increase in both the fresh and dry mass of shoots, numbers of sprouts, and length of the roots formed from the cuttings, when compared to the control treatment. Conversely, OLIVEIRA et al. (2008) assessed the effect of different IBA concentrations on $\boldsymbol{L}$. sidoides cuttings and showed that the number of shoots and roots developed per cutting decreased as the IBA concentration increased. According to these authors, the elevated endogenous levels of auxins, in addition to the effects of adding IBA, may have resulted in a phytotoxic effect.

From the above results, it is concluded that apical cuttings are the most suitable for the propagation of $\boldsymbol{L}$. insignis, while both apical and medial cuttings may be used for the propagation of $\boldsymbol{L}$. thymoides and L. lasiocalycina. In addition, the application of IBA is not necessary for the propagation of cuttings of the Lippia species studied.

\section{ACKNOWLEDGEMENTS}

The authors thank the Coordenação deAperfeiçoamento de Pessoal de Nível Superior (CAPES), the granting of scholarships, Fundação de Amparo à Pesquisa do Estado da Bahia (FAPESB), and the Conselho Nacional de Desenvolvimento Científico e Tecnológico (CNPq) for financial support.

\section{REFERENCES}

BIASI, L.A.; COSTA, G. Vegetative propagation of Lippia alba. Ciência Rural, v.33, n.3, p.455-459, 2003. Available from: $<$ http://www.scielo.br/scielo.php?script=sci arttext\&pid $=$ S0103-84782003000300010>. Accessed: Nov. 20, 2013. doi: $10.1590 / \mathrm{S} 0103-84782003000300010$.
BLANK, A.F. Transformation of genetic resources of native aromatic plants into wealth: the potential of Lippia gracilis. Horticultura Brasileira, v.31, p.512, 2013. Available from: $<$ http://www.scielo.br/scielo.php?pid=S0102053620130003000 29\&script $=$ sci_arttext\&tlng=en $>$. Accessed: Feb. 12, 2015. doi: 10.1590/S0102-05362013000300029.

LORENZI, H.; MATOS, F.J.A. Plantas medicinais do Brasil: nativas e exóticas. 2.ed. São Paulo: Nova Odessa, Instituto Plantarum, 2008. 576p.

OLIVEIRA, G.L. et al. Enraizamento de estacas de Lippia sidoides Cham. utilizando diferentes tipos de estacas, substratos e concentrações do ácido indolbutírico. Revista Brasileira de Plantas Medicinais, v.10, n.4, p.12-17, 2008. Available from: <http://www. scielo.br/scielo.php?script $=$ sci_nlinks\&ref $=000064 \&$ pid $=$ S0103847 8200900070003800013\&lng=en>. Accessed: Aug. 08, 2014.

PAULUS, D. et al. Vegetative propagation of Aloysia triphylla (L'Hér.) Britton according to IBA and length of cuttings. Revista Brasileira de Plantas Medicinais, v.16, n.1, p.25-31, 2014. Available from: <http://www.scielo.br/scielo.php?pid=S151605722014000100004\&script $=$ sci_arttext $>$. Accessed: Feb. 15, 2015. doi: 10.1590/S1516-05722014000100004.

PIMENTA, M.R. et al. Flowering, germination and rooting of cuttings of Lippia L. (Verbenaceae). Revista Brasileira de Botânica, v.30, n.2, p.211-220, 2007. Available from: <http:// dx.doi.org/10.1590/S0100-84042007000200006>. Accessed: Apr. 29, 2014. doi: 10.1590/S0100-84042007000200006.

TAVARES, I.B. et al. Types of cuttings and different substrates in the vegetative propagation of the Lippia alba (chemotypes I, II and III). Bioscience Journal, v.28, n.2, p.206-213, 2012. Available from: $<$ http://www.seer.ufu.br/index.php/biosciencejournal/article/ view/11328>. Accessed: Apr. 24, 2014. ISSN 1981-3163.

VICCINI, L.F. et al. Chromosome numbers in the genus Lippia (Verbenaceae). Plant Systematics and Evolution, v.256, p.171178, 2006. Available from: <http://link.springer.com/article/10 .1007\%2Fs00606-005-0351-3>. Accessed: Nov. 20, 2013. doi: $10.1007 / \mathrm{s} 00606-005-0351-3$. 